\title{
Towards a response to epistemic nihilism
}

Jake Wright, Center for Learning Innovation, University of Minnesota Rochester, Rochester, Minnesota, U.S.A.jwwright@r.umn.edu,

\begin{abstract}
This chapter develops an account of epistemic nihilism-roughly, the rejection of truth's intrinsic or instrumental value in favor of statements that reject or obscure truth to secure an advantage for the speaker-by examining three instances of such nihilism: lying, bullshit, and trolling. It further argues that epistemic nihilism, exacerbated by changes in the media landscape, can pose a significant threat to liberal democratic institutions and ideals by undermining the democratic ideal of good faith engagement on a level playing field, while also encouraging undemocratic actions (e.g., terrorism) among interlocutors who take the nihilist's claims seriously. Finally, this chapter argues that in extreme cases, we are justified in denying epistemic nihilists a platform from which to speak by drawing a parallel with vexatious litigant laws that deny individuals the right to petition courts for redress on the grounds that abuse of that right results in significant harm to both individuals and the legal system itself.
\end{abstract}

Key words: lying, bullshit, trolling, epistemic nihilism, Donald Trump, free speech

\section{Introduction}

On November 3, 2020, voters elected former Vice President Joe Biden as the $46^{\text {th }}$ President of the United States, defeating incumbent Donald Trump. Because the election took place amidst the Covid-19 pandemic, over 100 million voters - an unprecedented numbervoted early. This tsunami of early voting had a number of effects, including delayed votecounting in the decisive states of Michigan, Pennsylvania, Arizona, and Georgia. This delay meant that news organizations were unable to project a winner until the morning of November $7^{\text {th }}$ (Edelman 2020a) and that the final states of Georgia and North Carolina were not projected until November $13^{\text {th }}$, a full ten days after Election Day (Edelman 2020b). Such a delay was similarly unprecedented, ${ }^{1}$ since election winners are typically

\footnotetext{
I The closest modern parallel to the 2020 vote count is the 2000 presidential election, which was not resolved for over a month because of a miniscule margin in the ultimately decisive state of Florida. Following a series of recounts and legal challenges, George W. Bush was declared the winner by a
} 
known on election night. Further, because of partisan messaging regarding the safety of early voting and the manner in which votes were cast, ${ }^{2}$ several states that contributed to Biden's victory initially showed a significant lead for Trump that would later be chipped away at and ultimately surpassed by votes for Biden (Bronner, Wiederkehr, and Rakich 2020).

As a result of the delayed vote count and the marked shift towards Biden as early votes were tabulated, several right wing social media accounts pushed widespread narratives of voter fraud, leading to significant doubts about the fairness of the election and the validity of Biden's victory, especially among Republicans (Badger 2020; Mehta 2020). For example, in the three weeks following Election Day, Twitter flagged tweets from Donald Trump's account (@realDonaldTrump) over 200 times as containing false information about the election (Spangler 2020). These baseless accusations potentially undermine not only the perceived legitimacy of a Biden administration, but also faith in future elections.

Liberal democracy depends on good faith engagement. For example, democratic institutions must be responsive to stakeholders' needs via a 'process of reasoned discussion and deliberation on equal footing' (Christiano 2018). As Mill notes, 'the rights and interests of every or any person are only secure from being disregarded when the person

margin of 529 votes after the United States Supreme Court ordered an end to the recount in midDecember.

${ }^{2}$ Republicans, led by Donald Trump, largely tried to paint early voting as insecure and a source of widespread voter fraud, while Democrats encouraged early voting as a safe way to vote amidst a pandemic (Silver 2020). Thus, while early voting typically does not show a partisan lean in the United States, the early vote in 2020 skewed heavily towards Democrats. Further, in many states, in-person votes are tabulated first, with early votes counted later. Such states, like Pennsylvania and Georgia, showed an initial 'red mirage' due to Trump's significant lead in votes cast on election day itself. By contrast, states like Ohio and Texas, which counted early votes first, created a 'blue mirage' because the vote counting was reversed relative to states like Pennsylvania and Georgia. 
interested is himself able, and habitually disposed to stand up for them' (1861: 54). In short, the ideal of democracy involves participation by individuals who are forthright about their interests via good faith engagement on a level playing field. The further we slip from this ideal, the worse democracy operates — potentially to the point of a complete breakdown of democratic systems themselves. Efforts like those above, baselessly painting the legitimate winner of a presidential election as fraudulent are, simply put, not good faith engagement, and it is not hard to see how such efforts and the degree to which they have been advanced constitute a threat to democratic processes and institutions.

Recent scholarship has focused on rhetorical efforts to undermine the democratic process belying a commitment to good faith engagement, such as bullshitting and trolling. While efforts have been made to address such phenomena, they have largely focused on the individual phenomena themselves - for example, how we can disabuse belief in bullshit (Wright 2020a) or counter trollish behavior (Ebner 2019)—rather than considering these phenomena under a broader, more unified umbrella.

I have noted elsewhere that parallels existing between these phenomena are 'instructive and worthy of further study' (Wright 2020b) both because of their shared similarities as phenomena and because of the shared threats they collectively pose to democratic institutions. This chapter represents a first step in that further study, outlining what I term epistemic nihilism — briefly, a worldview that rejects the intrinsic value of truth — and outlining how we ought to respond to extreme cases of such nihilism. Essentially, cases of epistemic nihilism depend on rejecting truth as a necessary condition for achieving one's aims, often depending on one's interlocutor being unaware of this rejection. Thus, when deployed in the context of the democratic process, such actions 
constitute a form of cheating where one does not engage in good faith, creating an advantage precisely because one expects one's interlocutor to be engaging in the good faith that the epistemic nihilist has rejected.

The question thus becomes how we ought to respond to cases of epistemic nihilism. While a number of remedies exist to address one-off instances of nihilism - for example, the ability on many social media platforms to flag nihilistic posts for removal or as disputed - the question of how to respond becomes more challenging when considering serial offenders whose nihilism becomes something of a way of life. Put differently, we must consider what to do with, for example, serial liars, inveterate bullshitters, and unrepentant trolls who do not merely engage in nihilistic behavior but are properly considered epistemic nihilists. I argue that, in such extreme cases, we are justified in denying the nihilist a platform from which to speak.

Such a response is, in some sense, extreme, seeming to violate norms of discourse at a minimum and potentially violating rights to free speech at a maximum. I argue that such an extreme response is warranted when it is only through our ability to enforce such penalties that the nihilist's advantage can be countered, drawing a parallel with the legal designation of vexatious litigants, who are barred from petitioning the courts - despite the right to do so-specifically because the harm created by the vexatious litigant's abuse of that right. Put slightly differently, an epistemic nihilist like Trump might have the right to free expression under normal circumstances, but the abuse of that right to cause significant, repeated harm to democratic institutions may justify actions like denying a platform from which he can make his claims. 


\section{Epistemic nihilism}

I take epistemic nihilism to be the rejection of truth as an intrinsic or instrumental good. Often, discussions employing the term focus on at least the view that knowledge via universal epistemic principles is unobtainable, ${ }^{3}$ sometimes accompanied by further claims - for example, Nietzsche's claim that knowledge would not be useful if it were obtainable (Nehamas 2010) or Rorty's claim that epistemology as an enterprise is fatally flawed and should be dismantled (2009). When I use the term epistemic nihilism, however, I do not mean to suggest cases where a speaker believes that truth is unobtainable or cannot be adjudicated using universal principles, and I take epistemology generally to be a fruitful endeavor. Further, though I will not argue for it here, I accept a correspondence view of truth that accepts claims as true insofar as they align with an actual state of affairs in the world.

Perhaps the closest use of the term to my own is Arendt's view of nihilism as 'a way of thinking that can look rational but is really an attack on the purpose of rationality' (Gertz 2019: 104). As I discuss cases of epistemic nihilism, a common thread that emerges is the obscurance of truth because the truth is not valuable to the speaker who is attempting to influence their interlocutor's rational deliberations. This section examines such nihilism by considering the similarities between three exemplars of nihilistic speech-lying, bullshitting, and trolling — as well as the advantages of viewing activities like these as tokens of a larger type. I also discuss how epistemic nihilism can transcend individual instances and become an identity or way of life, which has implications for how we ought to respond when combatting extreme cases of such nihilism.

\footnotetext{
${ }^{3}$ See, for example, Goldman (20I0).
} 
It takes no great imagination to see how lying constitutes epistemic nihilism. The goal of a lie is to convince one's interlocutor to believe a falsehood spoken by the liar because their belief in that falsehood would advantage the speaker in some way. For example, one may lie and deny an extramarital affair, but such a lie would only be successful if the interlocutor (e.g., the speaker's spouse) believed the lie and presumably would be uttered only if the speaker viewed it as to their advantage. Even white lies-for example, the claim that dinner was delicious when it was not or that one's dress is attractive when it is not—advantage the speaker at some level, for example by allowing the speaker to seem supportive or to grease the wheels of social cohesion. Thus, the lie requires the recognition that the value of truth is outstripped by the value obtained by others' belief in one's falsehood.

Bullshit similarly rejects the value of truth, though for somewhat different reasons. Bullshit is essentially a claim that the speaker wishes their interlocutor to believe, though the speaker themselves has no regard for the claim's truth value (Frankfurt 1986). For example, Donald Trump regularly claims that unflattering coverage such as reports regarding crowd size (Concha 2018; Dale 2019; Levine 2019; O’Neil 2019), his handling of the Covid-19 pandemic (Trump 2020c), and his reelection campaign (Trump 2020b) is 'fake news.'

As I have argued previously (Wright 2020a), Trump's claims are bullshit precisely because of his aim in expressing them. Some cries of fake news are accurate, while others are not; Trump desires his audience to believe him not because they are true or false, but because they are unflattering. Unlike the lie, where truth matters, the truth value of the bullshitter's claim is simply irrelevant. 
As a third example, trolling differs from lying and bullshitting in that success depends not on the interlocutor believing the troll, but rather because the interlocutor is unsure what to believe because it is unclear what the troll believes. Essentially, trolling is a behavior in which outlandish claims are made or actions are undertaken for the purpose of garnering a reaction (Buckels, Trapnell, and Paulhus 2014; Edstrom 2016). Often, though not universally, such activities are otherwise aimless (Shachaf and Hara 2010), resulting merely from a desire to disrupt (Hardaker 2010). As noted later in this chapter, the generally aimless nature of most trolling provides vital cover for more nefarious instances of trolling that seek to disrupt in order to achieve a particular aim, like mainstreaming extremist views, retreating to familiar trollish responses that their actions are unserious and ought to be taken as such.

The generally provocative aim of trolling provides crucial cover for cases where trolling is employed as a recruiting or persuasive tool. For example, trolling often involves a 'humorous ambiguity [that] offers access points for undecided and not-yet politicized users to develop affinities with and support for far-right causes' (Bogerts and Fielitz 2019: 151) Such ambiguity allows the troll 'ironic distance' (May and Feldman 2019: 26) when the troll is confronted with claims that their speech or actions are out-of-bounds. Indeed, trolls typically respond that they are, in Internet parlance, 'doing it for the lulz, ${ }^{4}$ suggesting that their actions or speech ought not be taken seriously because they seek to provoke. This idea of doing it for the lulz suggests that there is something wrong with the interlocutor

\footnotetext{
${ }^{4}$ 'Lulz' is a transformation of the common chat/text acronym LOL (laugh out loud), frequently deployed when the goal is to generate laughter based on offensive or provocative behavior. For example, UrbanDictionary.com lists several user-provided definitions with examples, including 'Why did I post a giant image of 50 Hitlers? I did it for the lulz,' or claiming that Truman authorized the atomic bombings of Hiroshima and Nagasaki, killing 'thousands of innocent women and children... for the lulz' (Urban Dictionary n.d.)
} 
themselves because they took trolling at face value, rather than embracing the 'nothing matters' ethos of trolling (Wright 2020b).

\section{A unified theory of epistemic nihilism}

There are important differences between lying, bullshitting, and trolling, such as whether their success depends on the interlocutor believing a false claim or whether the interlocutor must believe the speaker is representing genuinely held views. Further, significant literature exists discussing how to address each activity individually, ranging from innumerable discussions of dishonesty in various subfields of applied ethics to discussions of the psychological motivations behind bullshit acceptance ${ }^{5}$ - as well as how to counter such openness ${ }^{6}$ — to strategies for countering trollish behavior. ${ }^{7}$

It is not my goal to suggest that nothing can be learned by such focused attention. Instead, I suggest that grouping nihilistic activities under a common umbrella also carries with it certain advantages. First, approaching the problem through a common lens allows us to note similarities between actions that abandon truth as useful or intrinsically good. Second, insofar as commonalities exist, we are better positioned to develop general strategies and apply extant strategies focused on one token of this type. Third, grouping actions under a common banner allows us to sidestep questions of taxonomy when such questions are not useful. We need not parse whether a difficult case is a lie, bullshit,

\footnotetext{
${ }^{5}$ See, for example, Nyhan and Reifler (2010); Pennycook and Rand (2018); Prior, Sood, and Khanna (2015); Schaffner and Luks (2018); and Wood and Porter. (2019)

${ }^{6}$ See, for example, Andre (1983), Delaney (2004), Erion (2005), Momeyer (I995), Paden (I987, I994), Satris (I986), and Wright (2019) for discussions of how to combat bullshit in a classroom environment.

${ }^{7}$ See, for example, Bogerts and Fielitz (2019), Ebner (2019), Edstrom (2016), May and Feldman (2019), and Tuters (2019).
} 
trolling, or something else if little rides on such a distinction; we may simply note an instance of epistemic nihilism and respond accordingly.

Many of the similarities between activities like lying, bullshitting, and trolling have been noted above. Briefly, each activity depends on rejecting the value or utility of truth in order to achieve some further aim by, for example, inducing one's interlocutor to believe a particular claim or to obscure the speaker's true beliefs or intent. Recognizing such similarities allows us to examine other behaviors with a critical eye towards whether they, too, constitute cases of epistemic nihilism. For example, one may examine the naïve skepticism often expressed by introductory-level students as a kind of (well-intentioned) nihilism that results from students' desires to avoid offense or appear tolerant (Wright 2019). Similarly, one might recognize that there are cases, like those discussed below, where one can engage in nihilism despite total transparency about one's genuine beliefs because the beliefs themselves are obviously nihilistic.

By collecting such disparate activities under a common framework, we can not only consider common responses - like my proposed response in this chapter - that may apply across all forms of epistemic nihilism, but also consider how particular targeted responses may be appropriated to respond to other forms of nihilism. For example, I have discussed how strategies for addressing naïve skepticism can be reapplied to combat people's openness to political bullshit (Wright 2020a). Certainly, there will not be perfect overlap in such cases, and differences between kinds of nihilism ought to be taken into account, but this is not, I take it, a reason to reject such considerations any more than being sensitive to the relevant details of a particular instance of bullshit is a reason to reject 
general anti-bullshit strategies. One may look for broad trends and general strategies while attending to the details of a particular case.

Indeed, there may be instances where working in broad strokes is preferable to a finegrained analysis. Such cases illustrate the third advantage of a broad theory of epistemic nihilism - the ability to sidestep irrelevant detail. To see what I mean, consider the following cases:

During racial justice protests in Buffalo, New York, an elderly peace activist named Martin Gugino was pushed to the ground by Buffalo police officers, hitting his head on the concrete sidewalk and sustaining a brain injury. Gugino's case attracted widespread media attention because video of the incident demonstrated that the officers' actions were unprovoked and directly contradicted an initial statement from the police department that Gugino 'was injured when he tripped \& fell' (Herbert 2020). Donald Trump responded to this incident by suggesting via tweet that Gugino was a member of antifa ${ }^{8}$ who had faked injury (Trump 2020a). Trump's tweet immediately drew widespread condemnation as 'baseless' (Spencer and Farley 2020), 'without evidence' (Phelps and Cathey 2020), a 'conspiracy theory' (Kessler 2020; Phelps and Cathey 2020; Reuters Staff 2020) and 'outrageous' (Kessler 2020). Because a Republican Senate conference lunch was scheduled for the afternoon Trump tweeted his comments, Republican senators became obvious media targets for journalists in search of comment. One such senator was Ron Johnson, who initially claimed to have not seen the tweet in question. But when asked by

\footnotetext{
${ }^{8}$ Antifa is an umbrella term for a loose collection of left-wing protestors formed in the wake of white supremacy protests in Charlottesville, Virginia in 2017 (Who are Antifa? n.d.) The term itself is a portmanteau of 'anti-fascist'.
} 
a reporter if he would like to have the tweet read to him so that he might comment, Johnson responded, 'I would rather not hear it' (Raju, Foran, and Fox 2020).

One might wonder how to classify such a comment, where the clear implication is a desire to avoid knowing the truth. The plain meaning of 'I would rather not know' is $a$ desire to not know rather than a desire to wait for context or a request for time to formulate a response. By saying he would rather not hear Trump's comment, Johnson is not lying; he genuinely did not want to know what Trump said. Neither was his comment bullshit, since the truth of Johnson's claim seems central to our analysis. Finally, it is not trolling, since there is no evidence Johnson made his remarks to get a rise out of reporters, In addition, there is no doubt about his genuine view. Yet his actions seem almost brazenly nihilistic; he simply declares he does not want to know the truth because the truth would be, in some sense, bad for him.

One might, out of a sense of charity, argue that Johnson may have demurred out of a wish to avoid commenting without knowledge of the full context. Even if we apply such strenuous credulity, however, Johnson's comment is a particularly overt instance of a pattern among Republican politicians who refuse to contradict obviously false, malicious statements by Trump to the point where 'Republicans asked about Trump's comments on $x$ ' has become something of a journalistic genre. Thus, it is instructive to consider a second example where, in response to Trump's baseless claims that he won the 2020 election and is the victim of widespread fraud, each Republican member of Congress was asked, one month after the election, who won the 2020 Presidential election. Out of 249 Republican members, 27 acknowledged former Vice President Joe Biden as the winner, two claimed that Trump had indeed won, and 220 refused to answer (Kane and Clement 2020). Like 
the Gugino case, Trump's false claims to be the victim of fraud are dangerous, but unlike the Gugino case, unfamiliarity with the issue is simply impossible, rather than seemingly implausible, since the question was posed a month after the election itself, after a clear winner had emerged. Yet again, it is not clear that those who refused to answer lied, bullshitted, or engaged in trolling.

Classifying such cases as instances of epistemic nihilism affords those of us who stand opposed to such behavior the opportunity to name it without having to more precisely diagnose or taxonomize. Insofar as labeling such remarks as instances of nihilism is sufficient in considering a response, further analysis is unnecessary. It is nihilism and ought to be treated as such.

\section{Epistemic nihilism as a worldview}

Thus far, discussion of epistemic nihilism has focused on individual cases in order to provide a sense of what sorts of actions constitute epistemic nihilism. However, it is important to note there is a difference between one-off instances and serial commission. For many of the actions that constitute epistemic nihilism, one common thread seems to be that repeated instances of such actions can impact one's identity through how one is perceived by others or how one perceives oneself. For example, we may judge one who lies regularly as a liar. 'Internet troll' is not merely pejorative; it can also be part of one's self identity, used to enforce community boundaries among fellow trolls (Bartlett 2014) or as justification for one's socially undesirable actions (Reed 2019).

If we take seriously the idea that repeated instances of particular forms of epistemic nihilism can result in identities like 'liar,' 'bullshitter,' or 'troll' either being assigned or 
self-declared, it seems one can similarly be an epistemic nihilist, full stop. It may be sufficient to note that an individual simply is an epistemic nihilist. Such labeling may be useful, both in terms of pushing back on more nuanced denials of being a liar, etc., but also because such labels have important implications for how we ought to respond in particularly egregious cases, as I discuss below. We may be justified in enforcing stricter penalties against a liar than one who lies occasionally, and we may be similarly justified enforcing strict penalties against epistemic nihilists. Before discussing how we ought to respond, however, it is worth discussing in some detail the threat posed by nihilistic behavior.

\section{The threat of epistemic nihilism}

Liberal democracy is premised on active, good faith participation from forthright members of the community, which provides a more-or-less level playing field. Epistemic nihilism rejects this premise by abusing the assumption that interlocutors are engaging in good faith. When successful, such actions advantage nihilistic behavior. In addition to providing a rhetorical advantage that is the direct result of bad faith engagement, nihilism has the further deleterious effect of encouraging conspiracists and other fringe actors willing to engage in actions well outside the scope of normal democratic participation. These advantages are further exacerbated by a balkanized media landscape that favors consumers' own partisan or tribal preferences, creating environments where nihilism is not adequately confronted.

The nihilist's rhetorical advantage 
It seems obvious that epistemic nihilism is advantaged over a commitment to truth and accuracy, since nihilistic speech need only be rhetorically advantageous, while truthful or accurate speech much also attend to those criteria. For example, the ironic distance provided by nihilistic acts like trolling allow an ambiguity that advantages the speaker by allowing a response to claims that one's speech is racist, misogynistic, and so forth along the lines that the speaker is only kidding or being provocative for provocation's sake, masking the speaker's seriousness with unseriousness (Bogerts and Fielitz 2019). Essentially, nihilistic speech need not reveal itself as such unless pressed, so potential fellow travelers who view such speech favorably gain access to the views expressed because opponents cannot clearly establish that the views are sincerely held by the speaker (May and Feldman 2019).

Nihilistic speech similarly advantages the speaker when the context of discussion drifts from sincerely held beliefs towards meta-discussion of the speaker's seriousness. There may be widespread agreement that sincerely believing a particular claim would be problematic. But the ironic distance provided by seemingly unserious provocation leads not to a discussion of the view itself, but whether the view is sincerely held or whether it is acceptable to insincerely express the view in question. When such debate occurs, the ironic or unserious use of language expressing genuinely held beliefs communicates meaning to those who understand the rules of a particular form of nihilistic communication as a form of dog whistle (Tuters 2019). The farcical nature of claims that Joe Biden's electoral victory was fraudulent has led to a robust meta-discussion of the degree to which these claims are genuinely held (Rucker, Dawsey, and Parker 2020), distracting from the 
fact that they are damaging precisely because they are false. Meanwhile, the message to those 'in the know' is quite clear; despite a clear victory free of fraud or interference, Joe Biden is not to be viewed as a legitimate president.

Finally, nihilistic speech allows for deflection or avoidance of undesirable lines of inquiry. Donald Trump, for example, has avoided questions about his rhetoric's effect on white nationalists by arguing such questions are themselves 'racist' (Farhi 2018). Similarly, he refused to answer a question about the removal of a high-ranking public health official who contradicted Trump's unsubstantiated claims about an ineffective Covid-19 treatment on the grounds that the reporter who asked the question was from a 'fake news' organization (Cortright 2020). Ron Johnson refused to hear what Trump had to say about the Gugino case. Like Trump's claims that his electoral defeat was the result of fraud, these cases drew media scrutiny away from the substance of the claims towards a general refusal to answer (Lewandowsky, Jetter, and Ecker Forthcoming).

Refusing to engage on specious grounds to avoid uncomfortable or unflattering lines of inquiry obscures what one believes, as well as why they believe it. At best, we as interlocutors are able to evaluate actions and motivations at a meta level, judging them for their willingness to obfuscate and engage in nihilistic behavior, rather than evaluate actions in their own right. We may, perhaps, infer certain things from how someone responds to certain questions, but inference is no substitute for a genuine answer.

\section{The dangers of nihilistic speech}

In addition to providing a rhetorical advantage, nihilistic speech can encourage actions that are anathema to reasoned deliberation that is the ideal of democracy. While the nihilist 
themselves might not be concerned with the truth, their interlocutors often are, thus creating the possibility of such individuals accepting genuinely dangerous claims.

For example, public health efforts aimed at reducing the spread of Covid-19 have been implemented to varying degrees of success globally. One of the largest factors impacting success is the degree to which they are countered by what the World Health Organization has called an 'infodemic' of misinformation (Evanega et al. n.d.; United Nations Department of Global Communications 2020). In the United States, preliminary analysis has found that the largest driver of misinformation has been Donald Trump himself (Evanega et al. n.d.). $37.9 \%$ of all misinformation captured by the study were directly associated with Trump, and a 'substantial proportion—possibly even the majority—of the [discussion surrounding] "miracle cures" (7) may have been driven by Trump as well, since he frequently touted supposed cures like hydroxychloroquine and injecting bleach. Such misinformation is not a theoretical exercise; it impacts individuals' view of the pandemic itself and the trustworthiness of genuine sources of medical knowledge. Partisan differences regarding the seriousness of the pandemic and the efficacy of preventative measures exist (Allcott et al. 2020) and can reasonably be explained, at least in part, by the fact that a major American political party is led by an epistemic nihilist.

The threat posed by nihilistic speech goes beyond public health, however, promoting actions that directly threaten the pillars of liberal democratic institutions. Adherents to QAnon - the conspiracy theory that Donald Trump is overseeing a federal investigation into Satan-worshiping, blood-drinking, cannibalistic Democratic Party leaders (including and especially 2016 nominee Hillary Clinton) and Hollywood celebrities who are collectively responsible for a global child sex trafficking ring (Neiwert 2018)— 
anxiously await the 'Storm,' supposed coordinated raids intended to crack down on the cabal (Coaston 2019). QAnon's growth has occurred on the far right with 'surprising rapidity' (Neiwert 2018), and a number of 2020 electoral candidates endorsed the theory either tacitly or explicitly. This includes Marjorie Taylor Greene, whose election to represent Georgia's $14^{\text {th }}$ district elevated an explicit adherent to the House of Representatives (Allam 2020). Following a congratulatory tweet to Greene after her victory in the Georgia primary, Donald Trump was asked whether he endorsed QAnon. Refusing to denounce the theory, he replied that he 'didn't know anything about them, other than they supposedly like me,' and that 'if I can help them save the world from problems, I'm willing to do it' (Rogers and Roose 2020).

It is not hard to imagine how such failure to denounce a conspiracy by its supposed leader can be viewed as at least tacit approval by conspiracists. Again, such seeming endorsement is no theoretical exercise; adherents have been described by the FBI as individuals willing to 'commit criminal and sometimes violent activity' (FBI Phoenix Field Office 2019: 1), and have, in fact, done so. QAnon conspiracists, along with adherents to QAnon's progenitor, Pizzagate, have attempted armed liberations of nonexistent trafficking victims, blocked traffic with an armored truck to force the release of nonexistent, supposedly confirmatory documents, and assassinated a member of the New York mafia because the crime boss was a purported member of the so-called 'deep state' conspiring against Trump (Amarasingam and Argentino 2020). In the latter case, the mafia assassin's lawyer reported that he viewed himself as 'Trump's chosen vigilante' (Amarasingam and Argentino 2020: 40). 
Such violence, generally speaking, is a breakdown of the sort of discourse democracy depends on; it is the application of power in lieu of reasoned discussion and deliberation. Thus, any violence is, at some level, problematic for democracy. But when such violence is cloaked in extrajudicial actions where conspiracist actors believe they have the tacit approval of the president, such violence becomes a threat to democracy itself. It does not matter whether the speaker actually believes in the underlying conspiracy theory. The refusal to say that a conspiracy theory is just that, instead remarking that one is 'willing to [help],' gives conspiracists permission to operate and act in a way that undermines democracy via terrorism and other actions anathema to democracy.

\section{The media's effect on epistemic nihilism}

Though the examples used throughout this chapter are recent, epistemic nihilism and its dangers are not new. Conspiracists have acted against the state long before the advent of 24-hour news, Tokyo Rose did not require the Internet to spread propaganda, and Socrates decried the rhetorical advantage of sophistry ${ }^{9}$ over two millennia ago. What has changed, though, is a media landscape which exacerbates the advantages of and dangers posed by epistemic nihilism. This change is the result of what Rose and Bartoli (2020) call the 'balkanization' of media, where previously hegemonic media structures like local and national newspapers or television networks are supplanted by an explosion of new journalistic and quasi-journalistic sources, reflecting both consumers' own partisan preferences and the shift towards so-called viral content.

\footnotetext{
9 See, especially, the dialogues Sophist, Gorgias, and Protagoras. John M. Cooper describes the Socratic view thusly: 'Though aware that he does not know anything, [the sophist] produces in words totally inadequate "copies" of the truth on important subjects, one he makes appear to others to be the truth, even though, being false, they are hardly even like it.' (Cooper 1997:326)
} 
Such balkanization can invite nihilism not only by catering to cognitive biases like motivated reasoning or intellectual laziness, but also because new media outlets often favor the enforcement of tribal boundaries over a commitment to truthfulness. For example, the conservative Gateway Pundit claims that they 'report the truth—and leave the RussiaCollusion fairy tale to the Conspiracy media' [sic] (Hoft n.d.). The conservative Daily Caller's Twitter bio brands itself as ‘[t]he journalists who love America' (@DailyCaller n.d.). Fox News successfully defended itself and its highest-rated host, Tucker Carlson, in a defamation lawsuit by arguing that the substance - not the expressed opinions, but the substance - of Carlson's commentary 'cannot reasonably be interpreted as facts' (Vyskockil 2020: 5) because 'given Mr. Carlson's reputation, any reasonable viewer "arrive[s] with an appropriate amount of skepticism" about the statements he makes' (12). In an environment where the epistemic nihilist seeks the cover of ambiguity to mask their beliefs or seeks to mainstream their beliefs by introducing them through seemingly respectable outlets in palatable forms, media balkanization is a godsend. As noted previously, ambiguity offers a powerful opportunity to introduce extremist ideologies, and mainstreaming can be easily bootstrapped in a media ecosystem of innumerable outlets. This is especially true when options include hyperpartisan outlets, as well as outlets committed to fastidiously presenting both sides of an argument, regardless of how supported the evidence for both sides is.

In the latter case, media's provision of so-called 'false balance' not only provides avenues for unsupported contrarian opinions, but also obscures the degree to which genuine expert consensus exists on phenomena like climate change (Koehler 2016; Merkley 2020; Park 2018). For example, a significant driver of the Covid-19 infodemic seems to have 
been that the overwhelming majority of Trump's baseless claims were not presented in a context where fact checking took place (Evanega et al. n.d.), obscuring the degree to which expert consensus was aligned against Trump's unfounded claims, creating an environment where Trump's claims seemed more reasonable than they objectively were.

\section{Countering epistemic nihilism}

Given the threats posed by epistemic nihilism, one might naturally ask how we ought to respond. Here, I argue that we must be willing, in extreme cases, to deny epistemic nihilists a platform from which to speak, similar to how vexatious litigants are denied the ability to seek relief from the courts. In both cases, denial seems to at least violate fundamental norms and may involve curtailing an individual's rights. Like the vexatious litigant, I argue that the epistemic nihilist may be denied a platform even though doing so may curtail free speech rights precisely because the way in which those rights are invoked are abusive and harmful.

Nihilistic speech succeeds because it is able to subvert the norms of democratic discourse that assume a level of good faith and honest representation of sincerely held views, for example, convincing interlocutors that insincere views are held sincerely, or masking sincerely held views behind a veil of ambiguity. Efforts to counter such speech face a trilemma, either (a) stooping to the level of the nihilist by employing nihilistic tactics, (b) using established norms to counter the nihilist, or (c) breaking established norms of discourse without resorting to nihilistic speech.

Embracing nihilism to overcome the nihilist is, I take it, a nonstarter. It may have the proximate effect of overcoming a particular instance of nihilistic speech, but the 
ultimate effect is a universal descent into nihilism. Surely the cure cannot be more of what ails us?

Ideally, nihilistic speech would be countered by employing strategies falling within established norms. For example, social medial platforms have begun applying tools meant to counter nihilistic behavior-like fact-checking, flagging, and post removal-more widely and evenly than in the past, going so far as to flag and remove posts made by political leaders, such as Facebook's and Twitter's removal of posts from Donald Trump claiming seasonal flu was more dangerous than Covid-19 (O'Sullivan 2020) or Twitter's flagging false and misleading claims about voter fraud and other issues with the tag, "This claim about election fraud is disputed" (Romm 2020). Such actions are the result of the claims at issue being both false and dangerous.

It would be best if the nihilist could be countered by such tactics, but it also seems reasonable to assume that staying within established norms of discourse will not always be successful precisely because of the advantages afforded nihilistic speech. Thus, there may be cases where one has no choice but to break established norms in an attempt to counter epistemic nihilism. The question is how best to do so, especially in edge cases where the nihilist's behavior is particularly egregious.

In extreme cases, the epistemic nihilist is essentially weaponizing the right to speak by abusing the assumption that interlocutors are operating in good faith. If this is so, we must be willing to deny the nihilist a platform. Nihilistic politicians, for example, ought not have their remarks broadcast, nor should they be the subject of interviews. Social media platforms must be willing to ban nihilists outright if other strategies prove unsuccessful. Obviously, such a strategy raises a number of concerns, from effectiveness 
to the rights of the nihilist to speak. There may be a public interest in knowing how a political figure explains policies, even if they do so nihilistically. Platform denial may be abused via partisan appeals to 'obvious' or 'widely accepted' truths that are genuinely disputed. Though space prevents a robust defense of each of these important concerns, I do note the following.

First, I acknowledge that attempts to ban lesser-known nihilists can result in a sort of whack-a-mole where the offending individual simply registers another account. Banning John Smith may not be as effective as banning Donald Trump, in part because of Trump's notoriety. However, I note that any roadblock that potentially slows or discourages nihilistic speech may be valuable. Also, John Smith cases seem unlikely to be the main focus of extreme measures like platform denial, since the potential harm of such anonymous actors seems far less likely to reach the point where extreme measures are warranted.

Second, I grant that the public right to know is vital to a healthy democracy and political leaders should generally be encouraged to explain their actions. However, the good faith assumed by such encouragement is precisely what the nihilist seeks to exploit to their advantage. Denying nihilists a platform not only neutralizes this advantage, but also potentially incentivizes good behavior; a platform may welcome back a sufficiently reformed or repentant nihilist. Nihilists who depend at some level on being well-knownlike politicians or media commentators - will not have the option of simply registering a new account and may be forced to choose between their nihilism and their access to a ready-made audience. 
Third, the decision to deny a platform to an epistemic nihilist is clearly value-laden. We deny nihilists a platform because their nihilism is dangerous (i.e., bad). Such value judgments risk smuggling in more problematic judgments, like denying a speaker a platform because their political views do not align with my own. Though such concerns are serious, a basic response can be offered by invoking Heather Douglas's (2009) distinction between the direct and indirect application of values in the decision-making process. While me may use our values to directly determine what sorts of actions are permissible - for example, the permissibility of denying a platform based on our values regarding liberal democracy—we may not use our values to directly determine what counts as an instance of permissible or impermissible action. Instead, we may use our values to indirectly inform how evidence in difficult cases ought to be evaluated. For example, it may be the case that one political party is more likely to engage in nihilistic behavior than another, and we may look more skeptically on the claims of that party as a result. But we may not simply say, 'They are Tories and are therefore denied a platform because I disagree with Tories.' On Douglas's view, we may rule out advocacy via epistemic nihilism in the same way we rule out human subject trials that do not obtain informed consent; our values as a society directly tell us that such efforts are impermissible. (Indeed, it is precisely the fact that such values ought to be forthrightly and openly deliberated upon that gives this discussion import.) But we cannot judge that a particular claim is an instance of nihilism or that a particular speaker is a nihilist simply because of their political views.

Finally, denying a platform does not constitute a violation of free speech rights. In the first place, my proposal does not call for imprisoning nihilists, nor am I arguing that the positions held by nihilists are automatically out-of-bounds. Instead, I argue we ought 
not provide platforms to egregious nihilists because of their tactics. If they wish to argue honestly for odious views, this discussion has nothing to say on the matter. Further, the denial of a platform is not speech prevention; it is at best an effort to curtail the reach of nihilistic speech to be heard. But the right to speak does not entail a right to be heard, an obligation to listen, or any obligation to amplify a speaker's message. In essence, it is a declaration that we collectively will not help nihilistic speech find an audience. If the speaker can find an audience or a fringe platform willing to countenance nihilism, that is their business. But even if denying a platform involved curtailing the right to speak, there are analogous circumstances demonstrating why such action is justifiable.

Within the U.S. legal system, as in many liberal democracies, individuals have a fundamental right to petition the courts to seek redress. Yet, there exist individuals who invoke this right to the point of abuse, using the system 'to harass [opponents], to postpone a result he considers unfair, or simply to satisfy some urge to engage in litigation' (Manwell 1966: 1770). Such litigants are harmful not only because of the harm they cause their legal opponents, but also the harm they cause the legal system itself by overtaxing it and preventing or delaying justice for petitioners whose motives are genuine. Thus, regular abusers may be legally declared vexatious litigants and prevented from filing further legal claims without involving outside counsel ${ }^{10}$ or the express permission of the courts. ${ }^{11}$

Two features of this designation are worth discussing here. First, a finding that one is a vexatious litigant goes beyond other measures intended to prevent frivolous lawsuits,

\footnotetext{
Io Vexatious litigants frequently represent themselves, and a requirement to obtain outside counsel discourages abuse because such counsel is equally subject to sanction if they themselves abuse the courts. As practicing lawyers whose livelihood depends on access to the legal system, they presumably do not wish such sanction.

II See, for example, California's vexatious litigant statutes (Title 3A: Vexatious Litigants I963.)
} 
like anti-SLAPP ${ }^{12}$ laws. It is an extreme response reserved for extreme offenders. Second, the bar that must be cleared for such a declaration is quite high, involving 'situations where litigants have filed dozens of motions either during the pendency of an action or relating to the same judgment' (Rushing 2007). In essence, one must engage in a great deal of genuinely harmful, specious litigation before being denied access to the courts.

The vexatious litigant designation and associated penalty is analogous to the sanction I suggest when denying epistemic nihilists a platform. My suggestion is not that we should liberally deny a platform at the first instance of nihilism or that no other steps be taken, but rather that extreme measures are justifiable in extreme circumstances. If there are individuals who cannot be trusted to engage in good faith, their refusal to do so poses significant harm, and less strenuous efforts have not proved corrective, we should be willing to deny them a platform.

\section{Conclusion}

Epistemic nihilism is all too common in contemporary discourse, in part because of the advantage it affords. While there are particularly obvious offenders whose speech regularly serves as a paradigm for nihilistic speech, like Donald Trump, it seems unlikely that one electoral defeat or one individual receding into the background of public life will address the wider problem of epistemic nihilism as a phenomenon. As research into the phenomena that constitute epistemic nihilism clearly demonstrates, Trump is not sui

\footnotetext{
${ }^{12}$ Anti-SLAPP (strategic lawsuits against public participation) statutes are intended to prevent litigants from filing lawsuits specifically designed to discourage public access to the courts by, for example, making participation so expensive as to be prohibitive. For example, a corporation may engage in SLAPP if they file a lawsuit against a critic they expect to lose, but the costs of defending oneself from the lawsuit would bankrupt the critic. Such suits incentivize not speaking out, even when making legally protected claims, by making the price of participation too high (Randazza 20I2).
} 
generis. There were epistemic nihilists before Trump, and there will be epistemic nihilists after Trump. If anything, Trump's success during his campaign and administration highlights the need for heightened vigilance so that the mistakes that led to the success of his nihilism will not be repeated.

While there are many steps one might take to discourage such nihilism, I have argued that, in extreme cases, we ought to simply deny the nihilist a platform from which to speak. Such sanction would apply only to egregious offenders whose nihilism is not only dangerous, but has not been corrected by more taciturn measures. While some platforms have taken steps to ban anonymous nihilists, such efforts do not seem to have extended regularly to more widely known offenders. Furthermore, when such deplatforming does occur, it is not only the exception to the rule, but it is also predicated on other behavior like abuse or sockpuppeting. Conspiracist Alex Jones, for example, has repeatedly suggested that the 2012 mass shooting at Sandy Hook Elementary was staged, but was banned from Twitter for abusive behavior towards other users (Schneider 2018). Similarly, the Krassenstein brothers, known mostly for hyperbolic criticism of Trump, were banned for maintaining multiple accounts under the guise that they were operated by different individuals, as well as purchasing interactions in order to publicize their antagonism of Trump (Concha 2019).

Clearly, the discussion here leaves many further questions to be answered, like what precisely constitutes an 'extreme' case or the precise circumstances in which we ought to deny nihilists a platform? But these, I think, represent fruitful avenues of future deliberation. Regardless of the specifics generated by such discussion, if we are to take the fight against epistemic nihilism seriously, we must be willing to not only take effective 
measures against nihilists and nihilistic speech, but also to apply those measures evenly, no matter who is engaging in such speech.

\section{Works cited}

Allam, H. (2020). From Fringe To Congress: QAnon Backers Are On The Ballot In November. $\quad$ NPR.org, 13 August. https://www.npr.org/2020/08/13/901985118/from-fringe-to-congress-qanonbackers-are-on-the-ballot-in-november. Accessed 30 December 2020.

Allcott, H. et al. (2020). Polarization and Public Health: Partisan Differences in Social Distancing during the Coronavirus Pandemic. Journal of Public Economics 19, 104254.

Amarasingam, A, \& Argentino, M.A. (2020). The QAnon Conspiracy Theory: A Security Threat in the Making? Combating Terrorism Center at West Point 13(7): 37-44.

Andre, J. (1983). Dealing with Naive Relativism in the Philosophy Classroom. Metaphilosophy 14(2), 179-82.

Badger, E. (2020). Most Republicans Say They Doubt the Election. How Many Really Mean It? The New York Times, 30 November. https://www.nytimes.com/2020/11/30/upshot/republican-voters-electiondoubts.htm. Accessed 30 December 2020.

Bartlett, J. (2014). OG Internet Trolls Are Upset Their Hobby's Been Ruined. Vice, 3 October. $\quad$ https://www.vice.com/en/article/bn538w/trolls-jamie-bartlett-289. Accessed 30 December 2020.

Bogerts, L., and Fielitz, M.. (2019). 'Do You Want Meme War?': Understanding the Visual Memes of the German Far Right. In Post-Digital Cultures of the Far Right: Online Actions and Offline Consequences in Europe and the US, Bielefeld, Germany: transcript Verlag, 137-54.

Bronner, L., Anna Wiederkehr A., and Rakich, N. (2020). What Blue And Red 'Shifts' Looked Like In Every State. FiveThirtyEight, 12 November. https://fivethirtyeight.com/features/where-we-saw-red-and-blue-mirages-onelection-night/ (December 17, 2020). Accessed 30 December 2020.

Buckels, E., Trapnell, P., and Paulhus, D. (2014). Trolls Just Want to Have Fun. The Dark Triad of Personality 67: 97-102.

California Code of Civil Procedure. (1963). 391 https://leginfo.legislature.ca.gov/faces/codes_displayText.xhtml?lawCode $=$ CCP\& division $=\&$ title $=3$ A. $\&$ part $=2 . \&$ chapter $=\&$ article $=($ October 29,2020$)$. Accessed 30 December 2020. 
Christiano, T. (2018). Democracy. In The Stanford Encyclopedia of Philosophy, ed. Edward N. Zalta. Metaphysics Research Lab, Stanford University. https://plato.stanford.edu/archives/fall2018/entries/democracy/

Coaston, J. (2019). The Mueller Investigation Is over. QAnon, the Conspiracy Theory That Grew around It, Is Not. Vox, 29 March. https://www.vox.com/policy-andpolitics/2019/3/29/18286890/qanon-mueller-report-barr-trump-conspiracytheories. Accessed 30 December 2020.

Concha, J. (2018). NYT Corrects Crowd Size Estimate at Nashville Rally after Trump Criticism. The Hill, 30 May. https://thehill.com/homenews/media/389925-nytcorrects-crowd-size-estimate-at-rally-after-trump-criticism. Accessed 30 December 2020.

—. (2019). Anti-Trump Krassenstein Brothers Receive Permanent Twitter Ban. The Hill, 24 May. https://thehill.com/homenews/media/445376-anti-trumpkrassenstein-brothers-receive-permanent-twitter-ban. Accessed 30 December 2020 .

Cooper, J. (1997). Plato: Complete Works. Indianapolis, Indiana: Hackett.

Cortright, B. (2020). Trump Refuses to Answer Question About Vaccine Expert's Reassignment. Independent Journal Review, 23 April. https://ijr.org/trump-refusesanswer-question-experts-reassignment/. Accessed 30 December 2020.

@DailyCaller. Daily Caller (@DailyCaller) / Twitter. Twitter. https://twitter.com/DailyCaller. Accessed 30 December 2020.

Dale, D [@ddale8]. (2019). Oh Man. I Was Just Watching Dozens of People Walk out of the Room as They Sensed Trump Was a Minute or Two from Concluding...Then Trump Said That He's Been Watching the Doors and Not One Person Has Left. https://twitter.com/ddale8/status/1101924636281974785. Accessed 30 December 2020.

Delaney, J. (2004). Tolerance and Tact: A Critical Thinking Strategy for Dealing with Relativism. Inquiry: Critical Thinking Across Disciplines 22(4): 27-31.

Douglas, H. (2009). Science, Policy, and the Value-Free Ideal. Pittsburgh: University of Pittsburgh Press.

Ebner, J. (2019). Counter-Creativity: Innovative Ways to Counter Far-Right Communication Tactics. In Post-Digital Cultures of the Far Right: Online Actions and Offline Consequences in Europe and the US, Bielefeld, Germany: transcript Verlag, 169-82.

Edelman, A. (2020a). Biden Defeats Trump to Win White House, NBC News Projects. NBC News, 7 November. https://www.nbcnews.com/politics/2020-election/biden- 
defeats-trump-win-white-house-nbc-news-projects-n1246912. Accessed 30 December 2020.

. (2020b). With Final States Called, Biden's Projected Electoral College Victory Matches Trump's in 2016. NBC News, 13 November. https://www.nbcnews.com/politics/2020-election/final-states-called-biden-sprojected-electoral-college-victory-matches-n1247766. Accessed 30 December 2020.

Edstrom, M. (2016). The Trolls Disappear in the Light: Swedish Experiences of Mediated Sexualised Hate Speech in the Aftermath of Behring Breivik. International Journal for Crime, Justice and Social Democracy 5(2): 96.

Erion, G. (2005). Engaging Student Relativism. Discourse 5(1): 120-33.

Evanega, S., Lynas, M., Adams, J, and Smolenyak, K. Coronavirus Misinformation: Quantifying Sources and Themes in the COVID-19 'Infodemic.' : 13.

Farhi, P. (2018). 'What a Stupid Question': Trump Demeans Three Black Female Reporters in Three Days. Washington Post, 9 November. https://www.washingtonpost.com/lifestyle/style/what-a-stupid-question-trumpdemeans-three-black-female-reporters-in-two-days/2018/11/09/272113d0-e44111e8-b759-3d88a5ce9e19_story.html. Accessed 30 December 2020.

FBI Phoenix Field Office. (2019). Anti-Government, Identity Based, and Fringe Political Conspiracy Theories Very Likely Motivate Some Domestic Extremists to Commit Criminal, Sometimes Violent Activity.

Frankfurt, H. (1986). On Bullshit. Princeton: Princeton University Press.

Gertz, N. (2019). Nihilism. MIT Press.

Goldman, A. (2010). Alvin I. Goldman. In A Companion to Epistemology, eds. Jonathan Dancy, Ernest Sosa, and Matthias Steup. West Sussex: Wiley, 144-52.

Hardaker, C. (2010). Trolling in Asynchronous Computer-Mediated Communication: From User Discussions to Academic Definitions. Journal of Politeness Research 6(2): 215-42.

Herbert, G. (2020). Buffalo Police Shove Elderly Man to Ground, Injuring Him; Claim He Tripped (Graphic Video). Syracuse.com, 5 June. https://www.syracuse.com/state/2020/06/buffalo-police-shove-elderly-man-toground-injuring-him-claim-he-tripped-graphic-video.html. Accessed 30 December 2020 .

Hoft, J. The Gateway Pundit - Where Hope Finally Made a Comeback. The Gateway Pundit. https://www.thegatewaypundit.com. Accessed 30 December 2020. 
Kane, P. and Clement, S.. (2020). Just 27 Congressional Republicans Acknowledge Biden's Win, Washington Post Survey Finds. Washington Post, 4 December. https://www.washingtonpost.com/politics/survey-who-won-election-republicanscongress/2020/12/04/1a1011f6-3650-11eb-8d38-6aea1adb3839_story.html. Accessed 30 December 2020.

Kessler, G. (2020). Analysis | Trump Tweets Outrageous Conspiracy Theory about Injured Buffalo Man. Washington Post, 9 June. https:/www.washingtonpost.com/politics/2020/06/09/trump-tweets-outrageousconspiracy-theory-about-injured-buffalo-man. Accessed 30 December 2020.

Koehler, D. (2016). Can Journalistic 'False Balance' Distort Public Perception of Consensus in Expert Opinion? Journal of Experimental Psychology: Applied 22(1): 24.

Levine, J. (2019). Donald Trump Calls Out Washington Post Reporter, Defends Inauguration Crowd Size. The Wrap, 8 May. https:/www.thewrap.com/trumpcalls-washington-post-reporter-defends-crowd-sizes. Accessed 30 December 2020

Lewandowsky, S., Jetter, M., and Ecker, U. (Forthcoming). Using the President's Tweets to Understand Political Diversion in the Age of Social Media. Nature Communication. https://psyarxiv.com/ar8d9/ (November 11, 2020).

Manwell, E. (1966). The Vexatious Litigant. California Law Review 54(4): 1769-1804.

May, R. and Feldman, M. (2019). Understanding the Alt-Right: Ideologues, 'Lulz' and Hiding in Plain Sight. In Post-Digital Cultures of the Far Right: Online Actions and Offline Consequences in Europe and the US, Bielefeld, Germany: transcript Verlag, 25-36.

Mehta, D. (2020). More Republicans Distrust This Year's Election Results Than Democrats After 2016. FiveThirtyEight, 20 November. https://fivethirtyeight.com/features/more-republicans-distrust-this-years-electionresults-than-democrats-after-2016. Accessed 30 December 2020.

Merkley, E. (2020). Are Experts (News)Worthy? Balance, Conflict, and Mass Media Coverage of Expert Consensus. Political communication 37(4): 530-49.

Mill, J.S. (1861). Considerations on Representative Government. Parker, son, and Bourn. https://www.gutenberg.org/files/5669/5669-h/5669-h.htm.

Momeyer, R. (1995). Teaching Ethics to Student Relativists. Teaching Philosophy 18(4): 305-11.

Nehamas, A. (2010). Friedrich Nietzsche. In A Companion to Epistemology, eds. Jonathan Dancy, Ernest Sosa, and Matthias Steup. West Sussex: Wiley, 551-52. 
Neiwert, D. (2018). Conspiracy Meta-Theory 'The Storm' Pushes the 'Alternative' Envelope yet Again. Southern Poverty Law Center. https://www.splcenter.org/hatewatch/2018/01/17/conspiracy-meta-theory-stormpushes-alternative-envelope-yet-again. Accessed 30 December 2020.

Nyhan, B. and Reifler, J. (2010). When Corrections Fail: The Persistence of Political Misperceptions. Political Behavior 32(2): 303-30.

O’Neil, T. (2019). Trump Insists 'Not One Person' Has Left — as People Are Walking out of His CPAC Speech. PJ Media, 8 May. https://pjmedia.com/video/trump-saysnot-one-persons-left-as-people-leave-his-cpac-speech. Accessed 30 December 2020.

O’Sullivan, D. (2020). Facebook Removes Trump Post Falsely Saying Flu Is More Lethal than Covid. CNN, 6 October. https://www.cnn.com/2020/10/06/tech/facebooktrump-covid-flu-false/index.html. Accessed 30 December 2020

Paden, R. (1987). The Student Relativist as Philosopher. Teaching Philosophy 10(2): $97-$ 101.

(1994). The Natural History of Student Relativism. The Journal of Thought 29(2): $47-58$.

Park, D. (2018). United States News Media and Climate Change in the Era of US President Trump. Integrated Environmental Assessment and Management 14(2): 202-4.

Pennycook, G. and Rand, D. (2018). Lazy, Not Biased: Susceptibility to Partisan Fake News Is Better Explained by Lack of Reasoning than by Motivated Reasoning. Cognition.

http://www.sciencedirect.com/science/article/pii/S001002771830163X.

Phelps, J. and Cathey, L. (2020). Trump Tweets Conspiracy Theory about Buffalo Protester Police Officers Knocked to Ground. ABC News, 9 June. https://abcnews.go.com/Politics/trump-tweets-conspiracy-theory-buffaloprotester-police-officers/story?id=71150154. Accessed 30 December 2020.

Prior, M., Sood, G., and Kabir Khanna, K. (2015). You Cannot Be Serious: The Impact of Accuracy Incentives on Partisan Bias in Reports of Economic Perceptions. Quarterly Journal of Political Science 10: 489-518.

Raju, M., Foran, C., and Fox, L. (2020). Senate GOP Dodges over Trump's Baseless Buffalo Tweet: 'I Would Rather Not Hear It.' CNN, 9 June. https://www.cnn.com/2020/06/09/politics/trump-buffalo-protester-set-uptweet/index.html. Accessed 30 December 2020.

Randazza, M. (2012). The Need for a Unified and Cohesive National Anti-SLAPP Law First Amendment Essays. Oregon Law Review 91(2): 627-34. 
Reed, L. (2019). 'Personally Invasive': Inside the World of 'Plainpotatoess,' SelfDescribed Troll. Washington Post, 12 February. https://www.washingtonpost.com/local/public-safety/personally-invasive-insidethe-world-of-plainpotatoess-self-described-troll/2019/02/12/62690100-2ef1-11e986ab-5d02109aeb01_story.html. Accessed 30 December 2020.

Reuters Staff. (2020). White House Defends Trump's Conspiracy Theory Tweet on Buffalo Protester. Reuters, 10 June. https://www.reuters.com/article/us-minneapolispolice-protests-buffalo-idUSKBN23H2AU. Accessed 30 December 2020.

Rogers, K. and Roose, K. (2020). Trump Says QAnon Followers Are People Who 'Love Our Country.' The New York Times, 19 August. https://www.nytimes.com/2020/08/19/us/politics/trump-qanon-conspiracytheories.html. Accessed 30 December 2020.

Romm, T. (2020). Twitter Labels Trump's Latest Claim about Election Fraud as 'Disputed' but Doesn't Limit Dissemination. Washington Post, 7 November. https://www.washingtonpost.com/technology/2020/11/07/trump-electionoutcome-tweet-label. Accessed 30 December 2020

Rorty, R. (2009). The Idea of a 'Theory of Knowledge.' In Philosophy and the Mirror of Nature, Thirtieth-Anniversary Edition, Princeton University Press, 131-64.

Rose, L. and Bartoli, T. (2020). Agnotology and the Epistemology of Ignorance: A Framework for the Propagation of Ignorance as a Consequence of Technology in a Balkanized Media Ecosystem. Postdigital Science and Education 2(1): 184-201.

Rucker, P., Dawsey, J., and Parker, A. (2020). Trump Insists He'll Win, but Aides Say He Has No Real Plan to Overturn Results and Talks of 2024 Run. Washington Post, 11 November. https://www.washingtonpost.com/politics/trump-election-resultsstrategy/2020/11/11/a32e2cba-244a-11eb-952e-0c475972cfc0_story.html. Accessed 30 December 2020.

Rushing, C. (2007). (California Court of Appeals) Morton v. Wagner.

Satris, S. (1986). Student Relativism. Teaching Philosophy 9(3): 193-205.

Schaffner, B. and Luks, S. (2018). Misinformation or Expressive Responding? What an Inauguration Crowd Can Tell Us about the Source of Political Misinformation in Surveys. Public Opinion Quarterly 82(1): 135-47.

Schneider, A. (2018). Twitter Bans Alex Jones And InfoWars; Cites Abusive Behavior. NPR, 6 September. https://www.npr.org/2018/09/06/645352618/twitter-bans-alexjones-and-infowars-cites-abusive-behavior. Accessed 30 December 2020.

Shachaf, P and Hara, N. (2010). Beyond Vandalism: Wikipedia Trolls. Journal of Information Science 36(3): 357-70. 
Silver, M. (2020). Some In GOP Fear Trump's Push Against Mail-In Voting Could Harm The Party's Chances. NPR.org, 31 August. https://www.npr.org/2020/08/31/907091223/some-in-gop-fear-trumps-pushagainst-mail-in-voting-could-harm-the-party-s-chanc. Accessed 30 December 2020

Spangler, T. (2020). Twitter Has Flagged 200 of Trump's Posts as 'Disputed' or Misleading Since Election Day. Does It Make a Difference? Variety, 27 November. https://variety.com/2020/digital/news/twitter-trump-200-disputed-misleadingclaims-election-1234841137. Accessed 30 December 2020

Spencer, S. and Farley, R. (2020). Trump Tweets Baseless Claims About Injured Buffalo Protester. FactCheck.org. https://www.factcheck.org/2020/06/trump-tweetsbaseless-claims-about-injured-buffalo-protester. Accessed 30 December 2020

Trump, D. [@realdonaldtrump]. (2020a). Buffalo Protester Shoved by Police Could Be an ANTIFA Provocateur. 75 Year Old Martin Gugino Was Pushed Away after Appearing to Scan Police Communications in Order to Black out the Equipment. (a) OANN I Watched, He Fell Harder than Was Pushed. Was Aiming Scanner. Could Be a $\quad$ Set https://twitter.com/realDonaldTrump/status/1270333484528214018. Accessed 30 December 2020

- (2020b). I Keep Reading Fake News Stories That My Campaign Is Running Low on Money. Not True, \& If It Were so, I Would Put up Money Myself. The Fact Is That We Have Much More Money than We Had 4 Years Ago, Where We Spent Much Less Money than Crooked Hillary, and Still Easily Won, 306-223! https://twitter.com/realDonaldTrump/status/1315871589129498625. Accessed 30 December 2020

_ (2020c). Totally Negative China Virus Reports. Hit It Early and Hard. Fake News Is Devastated. They Are Very Bad (and Sick!) People! https://twitter.com/realDonaldTrump/status/1316146752685174784. Accessed 30 December 2020

Tuters, M. (2019). LARPing \& Liberal Tears: Irony, Belief and Idiocy in the Deep Vernacular Web. In Post-Digital Cultures of the Far Right: Online Actions and Offline Consequences in Europe and the US, Bielefeld, Germany: transcript Verlag, $37-38$.

United Nations Department of Global Communications. (2020). UN Tackles 'Infodemic' of Misinformation and Cybercrime in COVID-19 Crisis. United Nations. https://www.un.org/en/un-coronavirus-communications-team/un-tackling$\% \mathrm{E} 2 \% 80 \% 98$ infodemic $\% \mathrm{E} 2 \% 80 \% 99$-misinformation-and-cybercrime-covid- 19 (October 29, 2020). Accessed 30 December 2020 
Urban Dictionary: Lulz. Urban Dictionary. https://www.urbandictionary.com/define.php?term=lulz (July 20, 2020). Accessed 30 December 2020

Vyskockil, M.K. (2020). (Southern District of New York) McDougal v. Fox News Network, $L L C$.

Who Are Antifa? Anti-Defamation League. https://www.adl.org/antifa (October 29, 2020). Accessed 30 December 2020.

Wood, T. and Porter. E. (2019). The Elusive Backfire Effect: Mass Attitudes' Steadfast Factual Adherence. Political Behavior 41(1): 135-63.

Wright, J. (2019). The Truth, but Not yet: Avoiding Naïve Skepticism via Explicit Communication of Metadisciplinary Aims. Teaching in Higher Education 24(3): $361-77$.

_ (2020a). 'Many People Are Saying...': Applying the Lessons of Naïve Skepticism to the Fight against Fake News and Other 'Total Bullshit.' Postdigital Science and Education 2(1): 113-31.

. (2020b). Review of Maik Fielitz and Nick Thurston (Eds.). (2019). Post-Digital Cultures of the Far Right: Online Actions and Offline Consequences in Europe and the US. Bielefeld: Transcript Verlag. 210 Pp. ISBN 978-3837646702 (Paperback). Postdigital Science and Education. 